\title{
Pendampingan Pastoral Terhadap Jemaat Yang Belum Siap Menghadapi Kematian di HKBP Pasar Minggu
}

\author{
Ruth Betty Panjaitan \\ Mahasiswa Pascasarjana STT Cipanas \\ ruthpanjaitanjurnal1@gmail.com
}

\begin{abstract}
Death is certainty for all living things. Even though the death sentence, but humans are very afraid of death and always try to avoid death. Even if the emergency condition of the congregation is critical, it is still not ready to face death, so it only needs to be healed physically. As an addition the makes the writer interested in doing pastoral care for canggregations who are not ready to death. Pastoral care uses interviews with five family members who are in critical condition and their family. This pastoral assintance uses the functions of sustaining and reconciling. This pastoral care can help fighy the pain. Then they will be reconciled by being able to help him. They can receive treatment for physicaly healing and also spiritual healing. Pastoral care is given to sick family members, families and also the medical team. How can the family enjoy a eternal life.
\end{abstract}

Keywords: Eternal life, dead, certainty, pastoral care, sustaining, reconciling, allow

\begin{abstract}
Abstrak: Kematian adalah kepastian bagi semua makhluk hidup. Walaupun kematian kepastian, tetapi manusia sangat takut terhadap kematian dan selalu mencoba menghindar dari kematian. Kondisi keadaan jemaat yang kritis sekali pun tetap belum siap menghadapi kematian, maka berusaha hanya untuk sembuh secara fisik. Keadaan seperti inilah yang membuat penulis tertarik untuk melakukan pendampingan pastoral kepada jemaat yang belum siap menghadapi kematian. Penelitian ini menggunakan metode wawancara kepada lima jemaat yang dalam kondisi sakit kritis dan kepada keluarganya. Pendampingan pastoral ini menggunakan fungsi Menopang (sustaining) dan mendamaikan (reconciling). Pendampingan pastoral ini menopang jemaat untuk menerima kondisi sakitnya. Maka mereka akan dapat didamaikan dan dapat memahami kehendak Tuhan dalam hidupnya. Mereka akan dapat menerima pelayanan untuk kesembuhan fisik dan juga kesembuhan rohani mereka. Pendampingan pastoral ini diberikan kepada jemaat yang sakit, keluarga dan juga tim medis.
\end{abstract}

Kata kunci: kehidupan kekal, kematian, kepastian, pendampingan pastoral, menopang, mendamaikan, merelakan

Article History

\begin{tabular}{|l|l|l|}
\hline Submitted: 28 Juli 2021 & Revised: 30 Juli 2021 & Accepted: 30 Juli 2021
\end{tabular}

\section{PENDAHULUAN}

Manusia sebagai makluk hidup pasti mengalami kematian. Kematian adalah kepastian, tetapi masih ada manusia yang tidak siap menghadapi kematian. Penyakit separah apa pun tetap saja manusia itu berusaha untuk tidak mengalami kematian. Usia yang sudah lanjut juga berusaha untuk tidak berhadapan dengan kematian.

Berpisah dari orang-orang yang sangat dikasihi merupakan alasan bagi jemaat sehinggah belum siap menghadapi kematian. Ketakutan meninggalkan anggota keluarga melalui kematian, juga merupakan alasan belum siap menghadapi kematian, mereka membayangkan kesulitan dan penderitaan yang akan dialami oleh keluarganya jika ia meninggalkan mereka melalui kematian. Alangkah indahnya jika 
manusia itu mempersiapkan dirinya bertemu dengan Tuhan, Sang Penciptanya, sehingga orang tersebut siap bertemu dengan Tuhannya dan orang-orang ditinggalkan juga rela memberangkatkannya menuju pada kematiannya.

Penulis membatasi masalah hanya kepada jemaat yang mengalami penyakit terminal. Dengan hipotesa pendampingan pastoral terhadap jemaat yang belum siap menghadapi kematian di HKBP Pasar Minggu dengan menggunakan pendampingan pastoral yang bersifat menopang (sustaining) dan mendamaikan (reconciling)

\section{METODE PENELITIAN}

Dalam tulisan ini, penulis akan menggunakan studi kepustakaan dengan menelusuri literatur terkait untuk menemukan bentuk pendampingan pastoral terhadap jemaat yang belum siap menghadapi kemartian. Bentuk pendampingan pastoral tersebut akan diimplikasikan kepada jemaat HKBP Pasar Minggu.

\section{HASIL DAN PEMBAHASAN}

\section{Kondisi Jemaat yang Belum Siap Menghadapi Kematian}

Setelah melakukan wawancara dengan beberapa jemaat HKBP Pasar Minggu yang mengalami penyakit terminal, ketidaksiapan mereka menghadapi kematian dengan menunjukkan sikap:

\section{Marah}

Ketika jemaat mengetahui bahwa dia mengalami penyakit terminal, dia marah karena tidak dapat menerima keadaan tersebut. Kemarahan ini ditujukan kepada dirinya sendiri, Tuhan dan keluarganya bahkan kepada para medis yang menangani sakitnya.

\section{Sedih}

Kesedihan mulai ditunjukkan ketika mereka mengetahui penyakit yang mereka derita. Perasaan sedih muncul saat membayangkan lama dan rumit proses penyembuhan yang akan mereka lalui.

\section{Malu dan menjadi tertutup}

Penderita memahami bahwa penyakit yang mereka derita akibat dosa dan kesalahannya. Mereka akan menjadi malu dan tertutup kepada orang lain.

\section{Putus asa}

Pasien membayangkan sulitnya kesembuhan yang akan mereka terima dan biaya yang mahal membuatnya menjadi enggan berobat. Pasrah terhadap keadaan. 


\section{Tinjauan Teoritis}

Menurut ilmu kedokteran kematian dibagi menjadi dua fase, yaitu somatic death (kematian somatik) dan biological death (kematian biologik) (A.M., 1997). Kematian somatik merupakan fase kamatian di mana tidak didapati tanda-tanda kehidupan lagi, seperti denyut jantung dan gerakan pernapasan, suhu badan menurun dan tidak adanya aktifitas listrik otak dalam rekaman EEG. Setelah dua jam, kematian somatik akan diikuti kematian biologik yang ditandai dengan kematian sel.

\section{Tinjauan Psikologi}

Kematian adalah bagian dari kehidupan, sehinggah jika berhadapan dengan kematian itu berarti kematian membuat kehidupan menjadi berakhir. Seperti yang dikatakan oleh Komarudin Hidayat dalam bukunya, kematian adalah sesuatu yang pasti dan tidak dapat lepas dari kehidupan manusia (Hidayat, 2006). Dua tokoh psikolog yaitu Freud dan Jung mengatakan dalam bukunya Komarudin Hidayat, bahwa ada hubungan erat antara kematian dan perilaku religius (Hidayat, 2006). Kematian yang tidak terelakkan itu akan menginsyafkan manusia akan ketidakberdayaan manusia tersebut. Sikap kecewa jemaat dalam menghadapi kematian, bukan hanya dirasakan oleh jemaat yang memiliki hubungan yang baik dengan Tuhannya, tetapi juga dirasakan oleh jemaat yang memiliki sikap tidak perduli dengan Tuhannya.

Hurlock Elezabeth dalam bukunya mengatakan pada orang lanjut usia memiliki kecendrungan penyakit kronis (menahun/berlangsung beberepa tahun) dan progresif (makin berat) sampai penderitanya mengalami kematian (Elizabeth, 1992). Proses penuaan yang dibarengi dengan penurunan daya tahan tubuh serta metabolisme sehingga menjadi rawan terhadap penyakit. Maka mereka akan mengalami persoalan psikologis, yaitu perasaan bosan, keletihan atau perasaan depresi.

Ketakutan yang amat sangat terhadap kematian atau proses kematian tersebutlah yang menjadi persoalan. Ketakutan yang tidak wajar inilah yang disebut tanatophobia atau fobia kematian, yang merupakan gangguang psikologis yang ditandai dengan rasa ketakutan yang ekstrem dan tidak masuk akal. Berbeda dengan fobia, yang mana manusia atau sipenderita tidak bisa mengendalikan perasaan takut tersebut (Jasad, 2018). Ketakutan yang berlebihan berdampak buruk bagi pihak yang merasakannya apabila terlalu berlebihan atau larut dalam perasaan takut tersebut. Jika perasaan ketakutan tersebut terus dibiarkan bertahan lama, hal itu akan berdampak buruk bagi kesehatan fisik dan mental pelakunya (Yulianto, 2015). 
Ketakutan yang berlebihan terhadap kematian seringkali menimbulkan gangguan fungsi-fungsi emosional normal manusia. Penelitian menunjukkan keterkaitan positif antara ketakutan terhadap kematian dengan gangguan emosional terhadap neoritisme, depresi, gangguan psikosomatis (Feifel \& Nagy, 1981). Tinjauan psikologi, yaitu dampak ketakutan dan kesedihan yang berlarut berpotensi terserang penyakit yang berbahaya. Lebih lanjut, Herman Yulianto mengatakan dalam bukunya, kesedihan dapat menimbulkan detak jantung yang dapat memicu tekanan dan pembekuan darah (Yulianto, 2015). Akibatnya potensi serangan jantung bertambah.

Ketakutan, marah dan menolak keadaan apabila berhadapan dengan kematian, hal tersebut merupakan sikap yang ditunjukkan oleh jemaat yang belum siap menghadapi kematian. Menurut penulis, pada kondisi yang demikian perlu peranan keluarga dan para medis serta kerabat untuk memberikan ketenangan dan kenyaman. Ketakutan dan kemarahan bukan saja dialami oleh penderita tetapi juga dialami oleh keluarga si penderita. Keadaan seperti ini perlu mendapat bantuan pendampingan pastoral agar dapat memahami dan menerima keadaan sehingga pengaruh dampak psikologi ini tidak dapat mengganggu proses pengobatan yang dilakukan.

\section{Tinjauan Sosiologis}

Budaya Batak merumuskan sejumlah jenis kematian, mulai dari status usia, jenis kelamin sampai usia tua, dari yang tidak diharapkan sampai yang diidamkan. Kematian bagi umat manusia dipahami sebagai kejadian yang sangat berat untuk dihadapi. Namun ada manusia yang menghadapi tantangan kematian dengan tetap melakukan ketaatan terhadap hukum agamanya (Johan, 2007).

Bangsa atau suku bangsa memiliki aneka kebudayaan yang beragam yang masing-masing memiliki ciri khas sendiri, tentang kematian. Masyarakat meyakini bahwa semua benda di sekeliling itu bernyawa atau memiliki roh dan semua yang bergerak dianggap hidup dan mempunyai kekuatan gaib (Koentjaraningrat, 2002). Secara tidak langsung kepribadian seseorang banyak dipengaruhi oleh lingkungan sekitarnya (Sarwono, 2002).

Bagi orang Batak, kematian yang paling tidak diinginkan adalah (Hutagalung, 2011): Pertama, kematian yang menjemput sebelum menikah. Mulai dari kematian dalam kandungan (mate di bortian), kematian saat bayi (mate poso-poso), kematian usia kanak-kanak (mate dakdanak), kematian usia remaja (mate bulung), kematian usia dewasa tetapi belum menikah (mate ponggol). Tidak ada upacara atau ritual adat untuk orang Batak yang mengalami kematian seperti itu, kecuali hanya pamannya (tulang/saudara laki-laki lbu) yang akan menutup sehelai ulos pada jenazah 
keponakannya itu (bere). Kedua, jenis kematian setelah menikah, yaitu meninggal dunia saat belum dikaruniai keturunan (mate punu), meninggal dunia ketika sudah dikaruniai anak, tetapi anaknya belum menikah (mate mangkar). Ketiga, meninggal ketika sudah dikaruniai anak, dan anaknya sudah menikah tetapi belum dikaruniai cucu untuknya (mate hatungganeon).

Orang Batak berdoa kepada Opung Mula Jadi Na Bolon, Tuhan Awal dan Akhir yang Maha Besar, agar terhindar dari kematian. Maka orang Batak kemudian merencanakan dan menjalankan kehidupannya untuk meraih tujuan kematian yang paling diidamkan tersebut. Sejatinya kematian memang tidak pernah diharapkan, kendati sudah diterima sebagai suatu kepastian bagi orang hidup. Tetapi budaya Batak membantu pemangkunya untuk merumuskan "kepastian kematian" itu baginya. Tinjauan Religius

Orang Batak percaya bahwa yang mati akan dibangkitkan untuk mempertanggungjawabkan amalnya. Hidup dan mati adalah satu hakikat yang sulit dibantah dan hampir tidak dapat disisihkan oleh manusia. Ketakutan dan kemarahan jemaat merupakan bukti dari sikap mereka yang tidak siap mengadapi kematian. Reaksi orang terhadap kematian tidak sama, ada yang pasip, menyerah karena kematian dilihat sebagai kejadian yang dikehendaki Tuhan, ada yang agresif, mengeluh, memberontak, memprotes karena tidak dapat menerima kematian, ada pula yang depresif, tertekan karena tidak mampu menanggung beban penderitaan yang disebabkan oleh kematian (Abineno, 2015).

\section{Tinjauan Teologis Tentang Kematian}

Kematian membuat keberadaan dan kehidupan manusia di dunia ini hilang atau lenyap, berakhir dan tidak ada lagi. Tubuh yang sudah menjadi jasad atau mayat akan menjadi membusuk, binasa dan habis. Dari tanah, kembali menjadi tanah (Sutarno, 2012). Dengan pemahaman ini, maka boleh dikatakan kematian adalah hal yang wajar dan alami, sebab setiap manusia akan mati pada waktunya masing-masing. Sehingga bisa dipahami bahwa kematian itu adalah kodrat atau ketetapan Sang Pencipta.

Jemaat mengalami penyakit terminal, mereka tidak siap menghadapi kematian, karena mengalami banyak kesukaran. Seorang dokter yang mengalami penyakit terminal dalam buku yang ditulisnya, mengatakan kesukaran-kesukaran yang dihadapi oleh pasien yang menghadapi penyakit mematikan adalah: percaya bahwa Allah ingin mengatakan kuasaNya melalui ketidakberdayaan kita (Casson, 2003). Hal ini bukan hanya menimbulkan konflik spiritual dalam diri kita, melainkan juga konflik fisik. 
Mungkin kita akan kecewa bahkan kesal, karena itu kita akan mudah terserang gejala stress (ketegangan).

Kemarahan akan memperburuk, seperti tidak bisa tidur, lesu, pencernaan yang tidak lancar, jantung yang berdebar-debar, buang angin dan sebagainya. Dosa-dosa lama terus menerus diingatkan, sehingga kita semakin bersalah. Tidak ada saat yang lebih tepat untuk mengandalkan pengampunan Allah dari pada saat kita mengenal persekutuan dalam penderitaan Kristus. Ketika jemaat mengalami penderitaan karena sakit yang dideritanya, terkadang penyakit itu menyebabkan mereka kehilangan iman mereka, yang menjadi rentan untuk jatuh kepada kepada keputusasaan.

\section{Pemahaman Teologi Kristen tentang Kematian}

Kitab suci memandang kematian sebagai hal yang alami (Maz 49:11-12) dan sebagai akibat dosa (Kej 3:19). Kematian adalah musuh terakhir yang harus dikalahkan (I Korint 15:26). Kematian adalah perpisahan antara tubuh dan jiwa/roh. Jiwa atau kesadaran tubuh yang tidak dimiliki roh (Yoh 2:2). Tubuh bersifat sementara atau fana (Rom 6:12) sedangkan jiwa/roh kekal (Mat 10:28) Karena itu kematian bukanlah merupakan akhir dari kisah kehidupan manusia. Ketika manusia mati, tubuh insanilah yang berakhir atau lenyap, sedangkan jiwa atau roh manusia tetap hidup (Keene, 2006).

Ajaran pokok mengeni kematian menurut Hendrik Nidjidah, dalam bukunya mengatakan (Nidjidah, 2003):

\section{Kematian sebagai akhir kehidupan}

Menurut pandangan ini, kematian merupakan akhir dari kehidupan manusia. Sebagai suatu makluk hidup yang fana, pada akhirnya manusia memang harus mati (Kej 2:7) supaya mereka dapat hidup dalam jangka waktu tertentu, tetapi tidak untuk selamanya (Kej 3:22), jika sudah sampai pada batas akhir hidupnya, maka manusia akan mati dan pergi, menempuh jalan segala yang fana (Yos 23:14 ; I Raja 2:2)

2. Kematian sebagai lawan kehidupan

Menurut pandangan ini, kehidupan itu selalu ditandai dengan keberadaan napas, sedangkan kematian ditandai dengan ketiadaan napas. Selama suatu makluk masih bernapas, dia akan bergerak dan berkomunikasi dengan makluk-makluk lainnya. Tetapi apabila dia sudah tidak bernapas lagi, maka dia sama sekali tidak dapat lagi bergerak dan berkomunikasi dengan pihak lain. Dalam pandangan bangsa Israel, hidup berarti bernapas (Kej 2:7), sementara mati berarti tidak bernapas lagi (Kej 35:18) 3. Kematian sebagai perusak kehidupan 
Mazmur menggambarkan kematian sebagai suatu kekuatan dalam bentuk banjir yang setiap saat mengancam seperti musuh yang menyerbu masuk melalui jendela untuk membinasakan manusia (Yer 9:21-22). Hosea melukiskan kematian sebagai binatang buas yang mengintip dan siap menerkam mangsanya (Hos 13:7-8). Kadang kematian digambarkan sebagai malaikat pemusnah, hantu malam, senjata serangga yang mempunyai sengat, berupa dosa, sehingga dapat menyebabkan kebinasaan manusia.

\section{Kematian sebagai tidur lelap}

Menurut pandangan ini, kematian merupakan suatu tidur lelap dan tidak pernah bangun lagi. Yeremia juga melukiskan kematian manusia sebagai jatuh tertidur untuk selama-lamanya, tidak akan bangun-bangun lagi (Yer 51:39-57) Anggapan ini juga dianut dalam kitab-kitab lain.

Sally Neparassi seorang pendeta mengatakan, "keterbatasan dan kefanaan manusia antara lain tampak dalam ketidakmampuannya untuk hadir di berbagai tempat sekaligus" (Neperasi, 2018). Sebab, manusia sangat terkait dengan ruang dan waktu. Tubuh manusia pun mudah terserang penyakit dan mengalami penuaan. Obat tercanggih sekalipun tidak dapat membuat manusia hidup untuk selama-lamanya. Sekuat apa pun tubuh manusia, pada akhirnya dia akan meninggal juga. Jadi kematian bagian dari siklus hidup manusia di dunia. Karena itu sama seperti kehidupan, kematian manusia juga berada dalam kuasa Allah.

Kamus teologi dapat diartikan, kematian sebagai akhir kehidupan jasmani yang terjadi secara otomatis, menurut waktu yang ditetapkan oleh Tuhan, dan tidak ada satu pun manusia yang mampu menolak kematian. Dengan kematian sejarah hidup kita dihadapan Allah mencapai bentuk yang lenyap dan tidak dapat diubahkan. Kitab suci memandang kematian sebagai hal yang alami (Maz. 49:11-12 ; 40:6-7) dan sebagai akibat dosa (Kej. 3:19 ; Roma 5:12) Kematian adalah musuh yang terakhir yang harus dikalahkan (I Kor. 15:26) dengan keikutsertaan kita dalam kebangkitan Kristus (Farrugia, 1995).

Kamus Pintar Alkitab menjelaskan tetang konsep kematian dalam bahasa Yunani menggunakan beberapa istilah untuk bisa menjelaskan konsep kematian yang dimaksud oleh alkitab tertuju pada Injil Lukas 16:19-31, kata "mati" yaitu nekrous (akusatif, plural, maskulin) dari kata nekros (Ef 2:1-5) berarti ebnoxious to death (kematian yang buruk, menjijikkan atau mortal yang mematikan). Kata nekrous juga berarti death (mati), lifelless (tidak berdaya), on a death person (orang mati), useless (tidak berguna, tidak bermamfaat) (Tacoy, 2012). Konsep kematian menurut Kamus 
Pintar Alkitab merupakan suatu keadaan buruk atau menjijikkan yang dialami oleh setiap manusia. Arti lain yang dijelaskan juga kematian itu disebabkan oleh "moral" artinya moral yang tidak benar itu yang mematikan, standard untuk mengetahui benar atau tidak benarnya moral manusia terhadap dirinya dan lingkungan di mana dia berlindung itu terukur dari norma-norma dalam undang-undang yang ditetapkan.

Dainton mengatakan bahwa menurut Perjanjian lama orang yang telah mati tetap berada di Syeol (Dainton, 2009). Bagi orang yang tidak percaya kepada Tuhan, Syeol adalah tempat yang muram tanpa suka cita. Bagi orang saleh ada harapan bisa ke luar dari Syeol karena mereka tahu Allah juga berkuasa atas Syeol. Artinya untuk dapat ke luar dari Syeol manusia harus berjuang keras menjaga kehidupan yang berkenan di hadapan Allah di masa hidup mereka, sehingga tanpa perlu merisaukan keadaan setelah mati nanti.

Kehidupan Kekal Setelah Kematian

Menurut teologi pada masa kini, alkitab telah menyaksikan bahwa segala perbuatan Allah penciptaan manusia dan pemeliharaanNya, pekerjaan penebusan dan pekerjaan pelepasan, semuanya itu hanyalah mempunyai satu tujuan, yaitu kedatangan serta pernyataan KerajaanNya. Gereja ditempatkan di dunia ini untuk memperdengarkan Inji tentang Kerajaan itu.

Sikap Yesus terhadap kematian, bahwa Yesus tidak mendukung pandangan yang mengatakan bahwa penderitaan dan kematian merupakan bukti bahwa orang telah berbuat dosa (Luk 13:1-5:"Dosa dan Penderitaan") Yesus tidak mengajarkan bahwa kematian mencemarkan, sekalipun menurut hukum Musa, kematian dianggap mencemarkan sampai pada tingkat bahwa seseorang yang menyentuh tubuh orang mati akan cemar (Mat 23:37) Sebenarnya Yesus tidak mengatakan apa-apa tentang kematian. Tanpa dihantui oleh pikiran mengenai kematian, Yesus menganggapnya sebagai suatu hal yang serius (Guthrie, 1993).

Bagi orang Kristen kematian itu sendiri seharusnya jangan dipandang sebagai persoalan. Sebagaimana yang dikatakan rasul Paulus:"Karena bagiku hidup adalah Kristus dan mati adalah keuntungan"(Filipi 1:21) Kematian bukanlah akhir, melainkan permulaan menuju kehidupan yang kekal.

Ketika Paulus dalam penjara, dia menantikan pemeriksaan perkaranya. Dia menghadapi dua kemungkinan, yaitu hidup dan mati. Namun kemungkinan mana pun bagi tetap sama. Kata "hidup" dalam frase yang luar biasa adalah Kristus. Bagi Paulus itu berarti Kristus adalah awal kehidupannya sebab pada hari ketika dia berjalan menuju Damaskus dia seolah-olah memulai hidup yang sama sekali baru. Kristus juga 
adalah hidup yang sedang dia jalani. Tidak ada satu hari pun dijalani Paulus tanpa kehadiranNya dan dalam saat-saat yang menakutkan Kristus hadir di sana untuk menghiburnya. Kristus adalah tujuan hidupnya dan inspirasi kehidupannya. Bagi Paulus Kristus telah memberikan kekuatan untuk menjalani hidup, sebab kasih karunia Kristus yang serba mencukupi telah menyempurnakan Paulus. Baginya Kristus adalah upah kehidupan sebab baginya upah satu-satunya yang berarti adalah hubungan yang semakin dekat dengan Tuhan (Barclay, 1999). Kematian adalah pintu masuk ke hadirat Kristus yang makin dekat.

Dampak kematian terhadap keluarga atau orang yang ditinggalkan amat dalam dan mempengaruhi aspek kehidupan jemaat baik fisik, mental, spiritual dan sosial. Secara fisik, seminggu setelah kematian adalah waktu di mana tubuh orang berduka berada dalam keadaan yang paling buruk dengan gejala-gejala bisa berupa sesak napas, dada terasa sakit, terjadi gangguan perut akibat penurunan sistem tubuh karena proses duka cita (Kolf, 1989). Gejala lainnya ialah sakit kepala, mati aras, gangguan tidur, kecapaiaan, berkeringat terus, amnesia dan sulit berkonsentrasi (Reece, 1999).

Pengharapan orang percaya adalah kedatangan Kristus yang kedua kalinya. Pengharapan ini berdasarkan janji yang Yesus telah ungkapkan kepada muridmuridNya dalam setiap pengajaranNya. Ungkapan Yesus ini bukan hanya bagi muridmuridNya yang mendengar perkataan Yesus pada saat ini, tetapi bagi setiap orang yang percaya kepada perkataan Yesus tersebut. Hal ini dikatakan dalam Titus 2:13 "Dengan menantikan penggenapan-penggenapan harapan kita yang penuh bahagia dan penyertaan kemuliaan Allah yang maha besar dan Juruselamat kita Yesus Kristus".

Perjanjian Baru selalu mengarahkan pandangan manusia kepada kedatanganNya yang kedua kalinya, mendorong jemaat untuk senantiasa siap untuk menyambut kedatanganNya. Dia akan datang dalam kemuliaan Bapa (Matius 16:27) Yesus berkata kepada imam besar bahwa dia akan melihat Anak manusia duduk di sebelah kanan yang Mahakuasa (Mark 14:62) (Hokoema, 2014). Hal ini berkali-kali Yesus sampaikan kepada para pendengar untuk bersiap-siap menantikan kedatanganNya kembali, sebab Dia akan datang pada saat yang tidak terduga (Mat 24:44; Luk 12:40).

Pengharapan terhadap kehidupan yang kekal setelah kematian, membawa jemaat memiliki pandangan yang optimis terhadap kematian. Jemaat percaya bahwa melalui kebangkitan Kristus, kematian telah kehilangan sengatnya. Kepercayaan yang 
optimis ini didasari atas pandangan bahwa maut masuk ke dalam dunia karena dosa (Roma 5:12) dan bahwa Kristus secara efektif telah memecahkan soal dosa itu. Jemaat tidak lagi memandang kematian sebagai musuh yang perlu ditakuti, tetapi malah sebagai titik transisi menuju semacam kehidupan yang lebih penuh.

\section{Pendampingan Pastoral bagi Jemaat yang Belum Siap Menghadapi Kematian} Pendampingan Pastoral

Fungsi pendampingan pastoral yang akan dilaksanakan kepada jemaat yang belum siap menghadapi kematian adalah fungsi menopang (sustaining) dan mendamaikan (reconciling). Manusia pada masa kini banyak sekali menghadapi berbagai masalah dan persoalan dalam hidupnya. Di tengah banyaknya persoalan yang dihadapi manusia, di situlah pentingnya pelayanan pastoral dalam pelayanan gereja. Pelayanan pastoral pada dasarnya merupakan pelayanan gereja yang mencerminkan pemeliharaan Allah terhadap ciptaanNya, secara khusus terhadap manusia. Pemeliharaan ini dalam alkitab, digambarkan seperti pemeliharaan yang dilakukan Gembala terhadap domba-dombaNya.

Pelayanan pastoral yang dilakukan gereja-gereja di Indonesia pada masa kini secara khusus gereja-gereja Protestan, dapat dikatakan sempit dan terbatas. Pelayanan pastoral yang sempit dan terbatas tergambar dalam Dokumen Keesaan Persekutuan Gereja-gereja di Indonesia. Dalam dokumen itu dituliskan bahwa penggembalaan adalah pelayanan gereja untuk memelihara, menuntun, membimbing, memberi pengertian, mengarahkan dan menyadarkan warga bagi keutuhan hidupnya, agar dia hidup di dalam kasih pengampunan dan keselamatan Allah dalam Kristus (D. Susanto, 2006). Pelayanan pastoral yang biasa dilakukan oleh gereja adalah secara individu. Hal inilah yang membuat pelayanan itu menjadi sempit dan terbatas.

Secara tradisional, pelayanan dan konseling pastoral hanya bersifat spiritual, menurut Mesach Krisetya, manusia dilihat sebagai makluk spiritual semata. Padahal manusia itu adalah makluk yang kompleks, manusia bukan sekedar hal yang rohani saja melainkan juga secara fisik, psikologis, mental-emosional dan sosial (Krisetya, 2015). Manusia terdiri atas beragam aspek yang tidak dapat dipisahpisahkan maka setiap pengambilan keputusan pastoral, kita hendaknya mau menerima masukan dari berbagai ilmu yang akan dilengkapi dengan keputusan teologis.

Daniel Susanto, sebagai seorang ahli pastoral mengatakan, pelayanan pastoral harus dipandang secara holistik. Pelayanan pastoral holistik tidak dilandasi oleh 
pemikiran teologi pastoral yang hanya berpegang pada gambaran antara gembala dan domba pada masyarakat agraris, seperti yang terdapat dalam alkitab (Daniel Susanto, 2016). Pelayanan pastoral holistik dilandasi oleh pemikiran bahwa pelayanan pastoral pada dasarnya mencerminkan pemeliharaan Allah terhadap ciptaanNya.

Susanto lebih lanjut menjelaskan dalam bukunya, bahwa pelayanan pastoral dapat diletakkan dalam karya Allah yang sedang memberlakukan kerajaanNya di dunia ini (Daniel Susanto, 2016). Menghubungkan pelayanan yang bersifat memelihara dan memperdulikan itu dengan kerajaan Allah berarti memperluas ruang lingkup pelayan pastoral sehingga pelayanan ini tidak hanya dibatasi pada manusia sebagai individu, tetapi juga pada masyarakat dan lingkungan hidup atau alam ciptaan Tuhan.

\section{Fungsi, Dasar dan Tujuan Pendampingan Pastoral}

Kebutuhan akan pendampingan pastoral dewasa ini semakina terasa diberbagai sektor kemasyarakatan, baik masyrakat kristiani maupun non kristiani. Krisis yang dialami oleh masyarakat, baik krisis ekonomi, sosial, politik dan krisis kesehatan, pendidikan maupun moral memicu kebutahan masyarakat akan pendampingan pastoral. Depresi dan stress, membuat masyarakat tidak ingin lagi hidup, mereka kecewa kepada manusia bahkan kecewa kepada Tuhan yang selama ini dipercaya sebagai Juru Selamat.

Bentuk pendampingan pastoral yang lajim dikenal adalah perkunjungan pastoral, percakapan atau konseling pastoral, petemuan-pertemuan dalam berbagai kelompok penopang (D. Susanto, 2006). Clinebell memberi pernyataan, bahwa pendampingan pastoral mencakup pelayanan yang saling membutuhkan dan menumbuhkan di dalam satu jemaat dan komunitasnya sepanjang perjalanan hidup mereka (Clinebel, 2006). Dalam pelaksanaan pelayanan pendampingan pastoral ini diperlukan orang lain yang membantu pendeta dalam melakukan pendampingan pastoral secara utuh. Menurut Daniel Susanto, pelayan pastoral pada dasarnya merupakan pelayanan yang memelihara dan memperdulikan (Daniel Susanto, 2008). Pelayanan ini dilakukan sesuai dengan fungsi pastoral yang dirumuskan dan dikembangkan oleh para teolog pastoral.

Dalam tulisannya, Daniel Susanto mengutip, mengatakan tentang fungsi dasar pastoral, Willianm A. Clebsch dan Charles R. Jaekle mengatakan ada 4 fungsi dasar pastoral yang dilakukan sepanjang sejarah gereja, yaitu: menyembuhkan (healing), menopang (sustaining), membimbing (guiding) dan mendamaikan (reconciling). 
Howard Clinebell menambahkan fungsi yang kelima, yaitu memelihara (murturing) (Daniel Susanto, 2008).

Penggunaan dari fungsi dasar tersebut tergantung pada proses dan kebutuhan yang didampingi. Misalnya, ketika mendatangi keluarga yang berduka, kehadiran seseorang pendamping yang mampu menopang/menguatkan keluarga dalam mengatasi kedukaan, merupakan fungsi awal yang harus diwujudkan. Dalam perkembangan pelayanan selanjutnya, pendamping boleh melihat bahwa anggota keluarga yang berduka mengalami ketertekanan dan kedukaan yang amat sangat, maka konselor perlu menghadirkan fungsi pembimbing (guiding). Secara filosifis praktis, fungsi dasar pastoral tersebut dapat dirunut dari konsep Perjanjian Lama dan Perjanjian Baru tentang gembala.

Manusia membutuhkan untuk saling menyembuhkan. Pendampingan ini dipahami sebagai proses pertolongan kepada sesama untuk secara terbuka dapat menjumpai dirinya sendiri dan menerima dirinya sebagaimana adanya. Pendampingan berarti kesediaan pendamping untuk bersama-sama dengan sesamanya yang ditolong tersebut menghadapi persoalannya. Dengan demikian pendampingan memang dapat dilakukan oleh semua orang.

J.L. Ch Abineno juga berpendapat bahwa dasar tindakan pastoral adalah pemeliharaan Allah kepada manusia. Jadi pelayanan pastoral berkata-kata tentang Allah, pemeliharaanNya, manusia dan keutuhannya (Abineno, 2016). Sesuai dengan fungsi kelima pendampingan pastoral yaitu memelihara (murturing) memampukan orang untuk mengembangkan potensi-potensi yang diberikan Allah kepada mereka, di sepanjang perjalanan hidup manusia. Manusia diharapkan dapat memelihara alam ciptaan Tuhan sehingga alam dapat hidup, bertumbuh dan berkembang biak.

Pendampingan Pastoral bagi Jemaat yang belum Siap Menghadapi kematian.

Pendampingan orang yang menjelang ajal umumnya belum ditangani dengan baik. Di zaman modren ini sikap orang terhadap kematian dan kondisi sekarat semakin ditandai oleh kecemasan, ketakutan ataupun sikap menghindar. Pandangan manusia dengan kematian masih identik dengan penderitaan dan kengerian. Pendampingan pastoral yang dilakukan bukan hanya kepada jemaat yang sakit tetapi juga kerabat dan lingkungan jemaat harus mendapat pelayanan pendampingan pastoral ini. Bukan saja jemaat yang sakit yang tidak siap menghadapi kematian, tetapi juga kerabatnya yang tidak siap menghadapi kematian keluarganya yang sakit tersebut.

Pendampingan yang dimaksud di sini adalah pendampingan iman. Manusia tetap dipandang sebagai manusia utuh, artinya manusia tidak dapat dipandang secara 
fisik saja. Manusia terdiri dari berbagai dimensi yang saling berhubungan. Tubuh manusia terdiri atas dimensi fisik dan psikologis serta dimensi sosial dan religiusspiritual. Dengan demikian jika manusia itu sakit, maka seluruh dimensi dalam dirinya juga terpengaruh.

Pasien penderita penyakit terminal dalam batas ketidakmampuannya secara manusiawi sering mengalami pergolakan dalam hidupnya, tak jarang mereka terpuruk dalam imannya mempertanyakan keberadaan Allah. Mulai menggugat Allah dalam situasi hidupnya (Kiessier, 1984). Rasa sakit yang berat membuat pasien marah kepada Allah. Allah yang selama ini penuh belas kasihan terasa hilang bahkan Allah sudah pergi meninggalkannya dalam situasi penderitaannya. Hal ini menggambarkan bahwa hidup beriman seseorang sungguh ditantang.

Penyakit terminal merupakan penyakit yang dialami oleh seseorang dan tidak dapat disembuhkan sehingga mengakibatkan kematian. Penyakit terminal ditujukan kepada seseorang yang mengalami suatu penyakit yang tidak ada obatnya sehingga mengancam kehidupannya. Penyakit terminal merupakan keadaan yang dialami individu yang mengalami kondisi medis dan pada akhirnya berakhir dengan kematian dalam waktu yang sangat terbatas.

Menurut seorang dokter, yang bernama Andry, mengatakan setiap orang pada suatu saat akan mengalami penderitaan, sakit dan kematian, karena ini merupakan hakikat manusia yang tidak terelakkan (Hartono, 2006). Keadaan sakit tidak dapat dipisahkan dari kondisi manusia. Sakit merupakan gejala umum dan biasa dan secara praktis sukar dipisahkan dari kehidupan manusia.

Menurut Boisen dalam bukunya Abineno mengatakan bahwa gangguangangguang psikis dapat disebabkan oleh hubungan sosial yang tidak lancar dan konflik yang tidak terselesaikan (Abineno, 2016). Pelayanan pastoral dilihat sebagai bantuan. Berdasarkan pengalaman hidup, maka pastor/pendamping harus belajar membaca orang yang bergumul dengan kesussahan dan penderitaan sebagai suatu dokumen manusiawi yang hidup.

Pendampingan pastoral perlu melibatkan keluarga pasien karena kehidupan dalam keluarga membentuk dan menentukan sifat atau karakter pasien yang juga dapat mempengaruhi respons pasien terhadap sakit yang dideritanya. Maka pendampingan sangat penting untuk memperhatikan hubungan keluarga. Konselor harus mengetahui pentingnya kehadirannya terhadap pasien dan keluarga

Menurut penulis perasaan emosional, seperti kesepian dan keterasingan dalam hubungan di keluarga dapat memperlambat proses penyembuhan. Kegagalan 
mengkomunikasikan hal inilah secara efektif dapat menjadi alasan seseorang berada di rumah sakit atau mengalami kelemahan fisik. Hubungan antara suami istri serta hubungan orangtua dengan anak membuat terjadi gangguan yang memicu penyakit dalam tubuh seseorang. Hubungan yang tidak baik dalam keluarga juga mempengaruhi pasien untuk bersemangat atau tidak dalam mengikuti setiap anjuran dokter untuk menerima kesembuhan.

Perasaan untuk dihargai dan menghargai adalah bagian dari kebutuhan manusia. Semakin manusia itu dihargai dalam keluarga dan lingkungan/sosial maka semangat untuk hidup akan semakin lebih besar. Seperti yang dikatakan Abraham H. Maslow dalam bukunya bahwa kebutuhan akan harga diri ini dapat diklarifikasi dalam dua bagian yaitu (Maslow, 1970): pertama kebutuhan akan prestasi, pemenuhan kebutuhan penguasaan dan kompetensi pengakuan di muka umum adanya kemerdekaan dan kebebasan. Kedua, kebutuhan akan reputasi dan prestise atau penghargaan dari orang lain, status, kemuliaan, kemasyuran dan dominasi. Apabila pasien merasa tidak dibutuhkan dalam keluarganya atau selama ini pasien kurang menghargai keluarganya atau kerabatnya akan mempengaruhi semangat untuk memperoleh kesembuhan.

\section{Pendampingan Pastoral: Menopang (Sustaining)}

Pendampingan Pastoral kepada jemaat yang belum siap menghadapi kematian, dilakukan dengan fungsi pandampingan menopang (sustaining). Melalui fungsi ini, pendampingan pastoral dapat menolong pasien agar dapat bertahan dan mengatasi keadaannya, karena penyembuhan atas penyakitnya tidak mungkin lagi diusahakan atau kemungkinan sangat kecil sehingga tidak dapat diharapkan lagi.

Pendampingan pastoral kepada jemaat yang belum siap menghadapi kematian. Gereja sangat sedikit memberi perhatiannya untuk menghantarkan jemaat tersebut menuju kepada kematiannya. Sekalipun kondisi jemaat tersebut sudah dalam keadaan kristis, berada diambang kematian karena kondisi fisiknya. Gereja hanya melakukan pelayanan memberikan semangat untuk menerima kesembuhan.

Kematian merupakan peristiwa yang membahagiakan bagi manusia yang menyakini kebahagiaan hidup kekal, yakni persekutuan antara manusia dengan Allah. Namun dalam kenyataan hidup manusia, persoalan menjadi sangat berbeda. Kematian menakutkan manusia, bahkan mendengar kematian dan melihat mayat orang merasa takut dan ngeri.

Fungsi menopang (sustaining) dalam pendampingan pastoral sangat dibutuhan bagi jemaat yang belum siap menghadapi kematian. Fungsi ini diwujudkan dengan 
menolong orang yang sakit atau terluka agar dia dapat bertahan dan mengatasi keadaan, di mana perbaikan seperti keadaan sebelumnya atau penyembuhan atas penyakitnya tidak mungkin lagi diusahakan atau kemungkinannya sangat kecil sehingga tidak dapat dipertahankan lagi. Menurut Clebsch dan Jeakle, fungsi menopang ini terdiri dari 4 tugas, yaitu: penjagaan (preservation), penghiburan (consolation), penguatan (consolidation) dan pemulihan (redemtion). Sehubungan dengan fungsi menopang, Hitler menegaskan bahwa berbeda dengan fungsi menyembuhkan di mana seluruh situasi masih dapat diubah, fungsi menopang ini berhubungan dengan situasi yang secara keeluruhan tidak dapat diubah atau sekurang-kurangnya tidak dapat diubah pada saat ini .

Orang-orang yang ditopang dalam pendampingan pastoral sering kali bertanyatanya tentang apa yang menyebabkan penderitaan mereka. Banyak orang yang menghubungkan penderitaan mereka dengan dosa dan hukuman Tuhan. Pernyataan seperti ini sebenarnya merupakan bentuk pencaharian akan Tuhan di dalam suatu penderitaan. Namun pendampingan pastoral hendaknya membiarkan pertanyaan seperti ini tetap terbuka. Yang pasti, Allah dekat dan memelihara manusia dalam penderitaannya, biarlah pertanyaan ini menjadi pergumulan iman mereka bersama dengan Tuhan.

Penopangan dilakukan supaya orang yang mengalami penderitaan berat tidak mudah kehilangan keyakinannya terutama kepada Tuhan. Oleh karena itu, orangorang terdekatnya ditopang supaya mampu mempertahankan semangat hidupnya, agar tetap bertahan dalam pengharapannya (Clinebel, 2006).

Pendamping diperhadapkan kepada pasien yang mengalami krisis mendalam (kehilangan/kematian orang-orang yang dikasihi, duka cita). Fungsi menopang adalah membantu pasien bertahan dalam situasi krisis yang bagaimana beratnya pun. Seperti yang dikatakan Aart van Beek bahwa dukungan berupa kehadiran atau sapaan yang meneduhkan dan sikap yang terbuka akan mengurangi penderitaan mereka yang walaupun hampir pasti tidak dapat mengubah kenyataan yang sudah ada namun setidak-tidaknya orang tersebut tidak merasa sendiri (Beek, 2017).

Begitu juga jemaat yang akan menghadapi kematian kerabatnya perlu penopangan sehingga jemaat yang mengalami krisis demikian tidak terperosok dalam suatu gangguan kejiwaan. Dengan pendampingan yang menopang dari pendamping maka pasien akan merasakan penguatan yang membuat pasien merasa tenang dan yakin. Seperti yang dikatakan James Halpern, ternyata orang yang sudah dekat waktunya untuk menghadap Tuhan, sangat membutuhkan waktu untuk berbicara dan 
mengalami keintiman yang tulus dengan orang-orang yang dikasihinya, sehingga seluruh keluarga bisa berkabung bersama dan bahkan bisa merencanakan hari depan (Halpern, 1987).

Menurut Mesach Krisetya ada 4 prinsip untuk mendampingi jemaat yang dengan masalah kematian, yaitu (Krisetya, 2015):

1. Prinsip Hadir (to be there), hal yang berharga dapat diberikan kepada jemaat yang menghadapi kematian adalah kehadiran yang penuh perhatian

2. Prinsip kedua, menjadi diri sendiri, ketika konselor melakukan pelayanan jadilah diri sendiri, tidak perlu menggunakan topeng profesional dan tidak berpura-pura memiliki jawaban untuk setiap pertanyaan atau pemecahan semua masalah.

3. Prinsip ketiga mendengarkan, mendengarkan berarti dengan sungguh-sungguh. Benar-benar peka terhadap muatan emosi dan perasaan di balik kata-kata yang diucapkan.

4. Prinsip keempat mencoba untuk mengerti. Ini adalah usaha untuk merasakan seutuhnya. Mengerti dan menerima perasaan-perasaan yang kurang enak tanpa mencoba untuk mengubahnya bisa menolong untuk memberi kelegaan kepada konseli.

Dalam melakukan pendampingan pastoral terhadap orang yang tidak siap menghadapi kematian, fungsi menopang sangat dibutuhkan dengan memperhatikan beberapa aspek, yaitu: 1. Percakapan terapeutik yang bukan nasihat, 2. Hubungan timbal balik, 3. Kecenderungan melakukan pelayanan tanpa tanggung jawab. Suasana percakapan konseling yang ideal meliputi persoalan-persoalan tentang: pengertian, empati, penerimaan, mendengarkan, refleksi dan respons.

\section{Pendampingan Pastoral: Mendamaikan (Reconciling)}

Fungsi pastoral mendamaikan adalah berusaha membangun kembali hubungan yang rusak antara manusia dengan sesamanya dan antara manusia dengan Allah (Daniel Susanto, 2006). Dasar pelayanan pendamaiaan sebenarnya terletak dalam karya pendamaian Kristus. Kristuslah yang pada dasarnya telah mendamaikan manusia dengan Allah, manusia dengan sesamanya dan manusia dengan lingkungan hidupnya.

Istilah rekonsiliasi merupakan gambaran penggenapan Allah di dalam Kristus mendamaikan hubunganNya dengan semua orang percaya dan dunia (2 Korint 5:19). Penderitaan merasa memiliki hubungan yang kurang baik dengan orang-orang di sekitarnya akibat perasaan sensitif akan kondisi keterbatasan fisiknya. Dia merasa terasing dengan dunia sekitarnya bahkan merasa tidak pantas (Clebsch \& Jaekle, 
1967). Manusia sebagai makluk sosial, apabila hubungan tersebut terganggu maka terjadilah penderitaan yang berpengaruh pada masalah emosional. Tidak jarang dengan adanya konflik tersebut, manusia tersebut akan menjadi sakit secara fisik yang berkepanjangan (Beek, 2017). Fungsi mendamaikan inilah merupakan pelayanan yang tepat dengan tujuan membantu orang-orang yang merasa terasing untuk membangun atau memperbaharui hubungan yang benar dengan Tuhan dan sesamanya.

Orang sakit dalam situasi berat, kritis dan dalam batas ketidakmampuan secara manusiawi sering mengalami pergolakan dalam hidupnya. Tidak jarang seseorang menderita sakit berada dalam ambang batas ketidakmampuannya, mempertanyakan keberadaan Allah dalam kondisinya/penderitaannya tersebut. Pasien akan mulai menggugat peran Allah dalam kondisinya/penderitaannya tersebut. Pasien akan mulai menggugat peran Allah dalam hidupnya. Rasa sakit yang berat sering membuat pasien marah kepada Allah dan melihat Allah sebagai Allah yang kejam dan tidak adil (Kiessier, 1984). Di sinilah pasien benar-benar merasakan bahwa hidup berimannya sungguh-sungguh sedang ditantang.

Dengan kehadiran pendampingan pastoral harus mendamaikan hatinya dangan mendampingi pasien agar dapat bertemu dengan Allah sekalipun dalam kondisi sakitnya tersebut. Fungsi mendamaikan dengan kahadiran pendamping di mana pasien mengalami tahap penolakan, kemarahan, tawar menawar, depresi, hingga tahap penyerahan diri. Pendampingan iman terhadap jemaat yang belum siap berhadapan dengan kematian, karena diyakini bahwa iman seseorang sungguh berperan untuk menumbuhkan suatu pengharapan. Iman berperan dalam ksembuhan, karena dengan iman seseorang dapat memberikan makna baru bagi pengalaman penderitaannya.

Kesembuhan secara fisik bukanlah satu-satunya yang diperjuangkan tetapi bagaimana seseorang menjadi pasrah akan kehendak Allah dan dimampukan memaknai hidupnya. Seperti yang dikatakan Ardy bahwa, "Iman menjadi suatu hal yang penting ketika sakit berat dan menghadapi kematian" (Hartono, 2006). Beriman kepada Allah yang senantiasa memberikan yang terbaik kepada hidup setiap orang yang percaya.

Para ahli melihat hubungan dekat antara iman dan penyembuhan. Kesimpulan yang mereka temukan adalah sebagai berikut: adanya hubungan yang erat antara agama dengan kesehatan, bahwa praktik religius merupakan faktor efektif dalam mencegah dan mengobati penyakit jantung, tumor ganas, dan gangguan kejiwaan 
(Jacob, 2003). Jadi boleh dikatakan dari hasil penelitian mereka bahwa agama meningkatkan harapan hidup.

Mendamaikan hubungan pasien dengan Allah akan menumbuhkan dan menguatkan iman pasien. Maka dengan iman, seseorang yang menderita sakit akan dibantu untuk melihat kembali makna hidup sekalipun dalam penderitaan fisik yang terbatas karena sakit. Dengan memampukan pasien menemukan makna baru dalam penderitaannya, pendamping telah melaksanakan fungsi pendampingan pastoral mendamaikan (reconciling). Seseorang dikatakan mengalami pendamaiaan jika sembuh secara mental dan rohani sakalipun pasien dalam keadaan sakit jasmani. Sehingga dalam sakit jasmani tersebut pasien menikmati dan menemukan makna hidup yang sejati dalam dirinya dengan merasakan bahwa Allah yang penuh kasih tetap mencintai dan memelihara hidupnya.

\section{Penerapan Pastoral terhadap Jemaat yang Belum Siap Menghadapi Kematian}

\section{Mengadakan Kunjungan Pastoral secara Rutin}

a. Mendengarkan pergumulan

Pendampingan pastoral yang dilakukan kepada pasien dalam hal ini menggunakan pelayanan percakapan pastoral. Dalam kunjungan Pendamping akan mendengarkan pergumulan, keluhan dan apa pun yang sedang dirasakan oleh pasien. Pendamping harus mendengarkan dengan kasih dan penuh perhatian.

b. Memberikan pemahaman tentang kematian

Dengan mempercakapkan kematian bukan berarti membiarkan pasien menyerah terhadap penyakitnya. Tetapi dipersiapkan untuk membayangkan yang sudah dekat yang akan dia hadapi.Artinya bukan hanya mendiskusikan tentang kesembuhan yang akan diperoleh oleh pasien, tetapi mengantarkan pasien bertemu dengan Pemiliknya.

Menopang dengan nyanyian

Nyanyian dapat memberikan kekuatan dan ketenangan hati, sehingga merasakan kesembuhan jiwa sekalipun fisiknya lemah.

\section{Mengadakan doa}

Doa adalah kekuatan orang percaya. Dengan berdoa pasien menerima kekuatan dari Tuhan.

Pendampingan pastoral kepada keluarga 
Kehadiran pendamping pastoral kepada keluarga bukan untuk menghalau kecemasan atau kesedihan dalam hati mereka, tetapi mendampingi keluarga agar mereka merasa dikuatkan.

\section{KESIMPULAN}

Berdasarkan pengamatan penulis, ketidaksiapan jemaat menghadapi kematiannya perlu menerima pelayanan pendampingan pastoral dengan menggunakan fungsi pastoral menopang (sustaining) dan mendamaikan (reconciling). Jemaat perlu diberikan penopangan tentang penyakit yang dideritanya agar mereka dapat bertahan dan sabar menghadapinya. Kesabaran yang mereka peroleh akan membuat mereka dikuatkan dan ditopang bahwa dalam sakitnya itu ada Kasihnya Tuhan yang tetap mereka rasakan dan yang menguatkan mereka.

\section{DAFTAR PUSTAKA}

A.M., I. (1997). Saat Kematian, Pedoman IImu Kedokteran Forensik. Bina Rupa Aksara.

Abineno, J. L. C. (2015). Pelayanan Pastoral Kepada Orang Berduka. BPK Gunung Mulia.

Abineno, J. L. C. (2016). Buku Pedoman Praktis untuk Pelayanan Pastoral. BPK Gunung Mulia.

Barclay, W. (1999). Pemahaman Alkitab Setiap Hari: Surat Filipi, Kolose, I dan 2 Tesalonika.

Beek, A. Van. (2017). Pendampingan Pastoral. BPK Gunung Mulia.

Casson, J. H. (2003). Kematian Petualangan Iman Terbesar dalam Hidup Saya,

Bagaimana seharusnya Sikap Kita Menyongsong Kematian. YKBK.

Clebsch, W., \& Jaekle, C. R. (1967). Pastoral Care in Historical Perspective. Harper

\& Row Publisher.

Clinebel, H. (2006). Tipe-Tipe Dasar Pendampingan dan Konseling Pastoral. BPK

Gunung Mulia.

Dainton, M. B. (2009). Apa yang Terjadi Setelah Kita Mati? YKBK.

Elizabeth, H. B. (1992). Psikologi Perkembangan. Erlangga.

Farrugia, E. G. (1995). Kamus Teologia. Fakultas Teologi Wedabhakti.

Feifel, H., \& Nagy, V. T. (1981). Another Look at Fear of Death. Journal of Consulting and Clinical Psichology, 49(2).

Guthrie, D. (1993). Teologi Perjanjian Baru 3 :Ekklesiologi, Eskatologi, Etika. BPK 
Gunung Mulia.

Halpern, J. (1987). Helping Your Aging Parents: A Practical Guide for Adult Children.

Fawcett Crest.

Hartono, A. (2006). Sembuh Karena Iman Pengharapan Dan Kasih. Kanisius.

Hidayat, K. (2006). Psikologi Kematian. Mizan Publika.

Hokoema, A. A. (2014). Alkitab dan Akhir Zaman. Momentum.

Hutagalung, B. (2011). Maragam-ragam Alai Sada. Kalangan Sendiri.

Jacob, B. (2003). Penyembuhan Yang Mengutuhkan. Kanisius.

Jasad, U. (2018). Semua Bisa Bahagia. Naura Books.

Johan, I. M. (2007). Kematian Manusia. Jurnal Ilmu Pengtahuan Budaya, 9(2).

Keene, M. (2006). Agama-agama Dunia. Kanisius.

Kiessier, B. (1984). Ikut Menderita, Ikut Percaya, Pastoral Orang Sakit. Kanisius.

Koentjaraningrat. (2002). Pengantar IImu Antropologi. Rieneka Cipta.

Kolf, J. C. (1989). How Can I Help ? Reaching Out To Someone Who is Grieving.

Baker Pub Group.

Krisetya, M. (2015). Bela Rasa Yang Dibagirasakan. Duta Ministry.

Maslow, A. H. (1970). Motivation and Personality. Harper \& Row Publisher.

Neperasi, S. (2018). Allah Merangkul, Memaknai Kehidupan dan Kematian Dalam

Allah. BPK Gunung Mulia.

Nidjidah, H. P. (2003). Misteri Kematian Manusia. Yayasan Pustaka Nasional.

Reece, G. W. T. (1999). Loss \& Bereavement: A Survivor's Handbook. Wipf and

Stock.

Sarwono, S. W. (2002). Psikologi Sosial : Individu dan Teori-teori Psikologi Sosial.

Balai Pustaka Jakarta.

Susanto, D. (2006). Pelayanan Pastoral di Indonesia Pada Masa Transisi, Orasi Dies

Natalis ke 72 STT Jakarta. UPI STT Jakarta.

Susanto, Daniel. (2006). Pelayanan Pastoral di Indonesia pada Masa Transisi. UPI

STT Jakarta.

Susanto, Daniel. (2008). Sekilas Tentang Pelayanan Pastoral di Indonesia. Majelis Jemaat GKI Menteng.

Susanto, Daniel. (2016). Pelayanan Pastoral Holistik Transformatif. In Panitia

Emeritasi Pendeta Daniel Susanto, Seputar Pelayanan Pastoral. GKI Menteng.

Sutarno. (2012). Menyongsong Kehidupan Sesudah Kematian. PT Pustaka Sinar Harapan.

Tacoy, S. M. (2012). Kamus Pintar Alkitab. Kalam Hidup. 
Yulianto, H. (2015). Mau Sehat Hilangkan Sifat Burukmu. Saufa. 